\title{
Almond Replant Disease and Its Management with Alternative Pre-Plant Soil Fumigation Treatments and Rootstocks
}

\author{
G. T. Browne, USDA-ARS CPGRU, Department of Plant Pathology, University of California, Davis 95616; \\ J. H. Connell, UC Cooperative Extension, Butte County, 2279-B Del Oro Avenue, Oroville, CA; and \\ S. M. Schneider, USDA-ARS, SJVASC, 9611 S. Riverbend Ave., Parlier, CA 93648
}

\begin{abstract}
Browne, G. T., Connell, J. H., and Schneider, S. M. 2006. Almond replant disease and its management with alternative pre-plant soil fumigation treatments and rootstocks. Plant Dis. 90:869876.

Trials were conducted in orchards near Chico, CA and microplots near Parlier, CA to examine symptoms and control measures for a replant disease (RD) on almond (Prunus dulcis). In the orchard trials, areas with a recent history of severe RD were cleared, given soil fumigation treatments in the fall, and replanted with almond trees on various rootstocks the following winter. The replants in nonfumigated soil developed severe RD (stunting, wilting, chlorosis, defoliation) by the following summer, while those in most fumigated treatments remained healthy. Trees in nonfumigated soil developed smaller trunk diameters and fewer healthy roots $\leq 1 \mathrm{~mm}$ diameter, compared with the healthy trees. Almond developed RD on all rootstocks evaluated (Marianna 2624, Lovell, and Nemaguard), but the trees on Marianna 2624 were the most severely affected. Pre-plant tree-site (spot) fumigation treatments with methyl bromide (MB), chloropicrin (CP), 1,3-dichloropropene (1,3-D), 1,3-D + CP, iodomethane, and iodomethane + $\mathrm{CP}$ all prevented severe RD. Broadcast soil fumigation with $\mathrm{CP}$ also was effective, but broadcast $\mathrm{MB}$ and 1,3-D were ineffective. In microplots filled with RD-conducive soil, $\mathrm{CP}$ was more potent than MB for prevention of RD on Nemaguard peach. There was no association between nematodes and RD in orchard or microplot trials. The RD apparently was mediated by a biological agent(s) other than nematodes and can be prevented by appropriate fumigation with CP or other MB alternatives.
\end{abstract}

Additional keywords: Prunus persica, stone fruit replant disorder

Young trees of stone fruits (i.e., species of Prunus) often suffer from diverse replant problems that cause them to grow suboptimally or, in severe cases, die when planted after other crops. Some replant problems result in part or primarily from abiotic causes. For example, nutrient deficiencies and toxicities, improper soil $\mathrm{pH}$, and soil compaction associated with previous crop production can impede development of replanted orchards (15). Most replant problems, however, have strong microbial components. For example, populations of plant-parasitic nematodes, fungi, and Phytophthora spp. can increase in orchards and singly or collectively cause disease on replanted stone fruits (15). Several species of endo- and ectoparasitic nematodes attack the roots of fruit and nut crops in California $(27,28)$, and pre-plant soil fumigation treatments typically are

Corresponding author: G. T. Browne

E-mail: gtbrowne@ucdavis.edu

Accepted for publication 22 January 2006

DOI: 10.1094/PD-90-0869

This article is in the public domain and not copyrightable. It may be freely reprinted with customary crediting of the source. The American Phytopathological Society, 2006. directed at these pests. Even in the absence of known pests and pathogens, however, young trees of Prunus spp. tend to lag in growth and productivity when planted after a previous generation(s) of the same crop (15). We advocate using the terms "replant disorder" and "replant disease" in reference to replant problems resulting primarily from abiotic and biotic causes, respectively.

In the northern part of California's Central Valley (i.e., Butte County), we have repeatedly observed poor vegetative growth and high incidences of tree mortality ( $\geq 50 \%)$ in young almond (Prunus dulcis) orchards planted on land with a longterm history (i.e., more than 10 years) of almond production (J. H. Connell and G. T. Browne, unpublished). The replant failures were not apparently associated with known pests or pathogens or substandard horticultural practices. Although the disease is not always apparent where almond is planted after almond, we have not observed it where almond is planted on sites devoted to herbaceous crops for many years. Symptoms and circumstances of the disease bear similarity to a previously described peach replant problem in California $(5,23-25)$, but we are aware of no formal characterization of replant disease (RD) on almond.
Previous research has illustrated the etiological complexity of RD in Rosaceous and other plants. In 1941, a "peach replant problem" not associated with plantparasitic nematodes or other known root pathogens was reported in California (25); peach after peach was affected, but not peach after apple (24). Application of macro and micro nutrients failed to alleviate the problem. In soils infested with Pratylenchus penetrans and collected from apple, cherry, and pear orchards, RD on apple, cherry, and pear seedlings was partially controlled by pre-plant fumigation with dichloropropene-dichloropropane, but fumigating the soils with chloropicrin $(\mathrm{CP})$ or autoclaving them before planting was more effective (16). The RD was attributed to parasitism by the nematode and other unknown biological agent(s). Union mild etch, a disorder of young almond trees on Marianna 2624 rootstock, has interfered with the development of young orchards in Northern California (30). Evidence has been presented for a role of toxigenic peach root residues in peach replant problems $(7,22,25)$, but the reports have not found consistent support $(10,14)$. In the state of Washington, apple replant disease was shown to result primarily from root infection by Cylindrocarpon destructans, Phytophthora cactorum, Pythium spp., and Rhizoctonia solani (18). For many plant species, depressed growth or yield has been associated with deleterious rhizosphere microorganisms that negatively affect plants without parasitizing them $(1,26)$.

Improved management strategies are needed for $\mathrm{RD}$ on almond. Land area planted to the crop has roughly quadrupled in the last 30 years in California, and the risk of almond replant problems is expected to increase as the growing districts age. Pre-plant soil fumigation with methyl bromide (MB) has been used to prevent replant problems in deciduous tree plantings, but the fumigant is being phased out due to its ozone depleting potential. Alternative fumigants are available, but research is needed to test their efficacy and optimize their application for management of replant problems. All fumigants may face increased regulatory constraints in the future, and research is needed to develop cultural and biological approaches for managing replant problems. Little is known concerning tolerance of different almond rootstocks to RD. 
The objectives of the research reported here were to characterize effects of RD on almond tree growth and development and to develop effective control measures for the disease. A portion of this work was reported previously (3).

\section{MATERIALS AND METHODS}

Orchard trials. Replanting trials were conducted from 2000 to 2005 in three commercial orchards within $20 \mathrm{~km}$ of Chico, CA (orchards 1, 2, and 3; details in sections below). Depending on the orchard, the soils were Nord loam (taxonomic class: Coarse-loamy, mixed, superactive, thermic Cumulic Haploxerolls), $\mathrm{pH}$ 7.4; or Farwell loam (Fine-loamy, mixed, superactive, thermic Fluventic Haploxerepts), $\mathrm{pH} 7.2$ to 7.4. The orchards had been in commercial almond production for at least 15 years before the experiments. In the year before the trials, the growers had cleared and replanted the orchards with almond trees. The new orchards suffered a high incidence of severe RD (i.e., failure of $>50 \%$ of replanted trees in land areas covering $>2$ ha) in the first year after planting. The affected areas were cleared again, and replant trials involving different preplant fumigation treatments and almond rootstocks were established where disease incidence and severity had been greatest.

Microplot trials. Additional replant trials were conducted from 2000 to 2004 in microplots at the USDA-ARS San Joaquin Valley Agricultural Science Center, near Parlier, CA (details in sections below). The microplots were open-ended $0.5-\mathrm{m}$ diameter $\times 1.2-\mathrm{m}$-long sections of concrete pipe inserted lengthwise into holes in the ground and filled with soil. The soil, Hanford fine sandy loam (Coarse-loamy, mixed, superactive, nonacid, thermic Typic Xerorthents), $\mathrm{pH} 7.6$ to 7.8 , was collected from 0- to 0.2-m depth in an adjacent peach orchard. Replant trials involving Nemaguard peach seedlings (a common rootstock for almond) and different preplant fumigation treatments were established in a new set of the microplots each trial year.

Pre-plant fumigation. In the orchard trials, depending on the year and experiment, pre-plant fumigation occurred from 21 October to 1 November. Within an experiment, all fumigation treatments were applied on the same day. The soil at 10 to $60 \mathrm{~cm}$ depth was 14 to $20^{\circ} \mathrm{C}$ and had moisture contents from 0.14 to $0.31 \mathrm{~kg}$ per $\mathrm{kg}$ of oven-dry soil.

Broadcast soil fumigation treatments were applied in one orchard trial (experiment 1, described below). The soil had been prepared by deep cultivation followed by harrowing to smooth the soil surface. Fumigants were injected into the soil at a depth of 40 to $50 \mathrm{~cm}$ through tractorpulled shanks spaced $50 \mathrm{~cm}$ apart. A roller attached to the back of the fumigation rig compressed the soil surface immediately after the fumigants were injected to prevent premature escape of the gas.

Planting-site spot fumigation treatments were applied in several orchard trials (experiments 2 to 5 and 9 to 11 described below). Planting sites were prepared for fumigation with a tractor-powered auger, which removed the soil from 50- to 60-cmdeep $\times 60$-cm-diameter holes. The loose soil was pushed back into and mounded above the holes. Fumigation treatments were injected through a 1-cm-diameter hollow metal probe that was inserted to a depth of 45 to $50 \mathrm{~cm}$ in the center of the soil-filled holes. At its upper end, the probe was connected to a pressurized supply of fumigant. After fumigation, the soil surface was compressed over the injection hole to prevent premature escape of the fumigant.

In microplot trials (experiments 6 to 8 , described below), pre-plant soil fumigation treatments were applied, depending on experiment, on 30 April 2002, 20 November 2002, or 19 November 2003. The soil at 10 to $45 \mathrm{~cm}$ depth was 11 to $30^{\circ} \mathrm{C}$ and had moisture contents from 0.07 to $0.13 \mathrm{~kg}$ per $\mathrm{kg}$ of oven-dry soil. Before fumigation, the soil was cultivated with a hand shovel to a depth of $0.4 \mathrm{~m}$ and tamped moderately at the surface. Fumigants were injected into the soil at a depth of $30 \mathrm{~cm}$ near the center of each microplot through an 8-mmdiameter hollow metal probe. The probe was connected by flexible tubing to a frame-mounted gas-tight syringe (Hamilton Company, Reno, NV) that was used in a valve-controlled closed supply system to deliver fumigation treatments. After fumigation, the soil surface was compressed over the injection hole, and virtually impermeable film (VIF) mulch (Bromostop, Bruno Riminni, Ltd., London) was used to seal the top openings of the microplots. Control microplots were cultivated, tamped, and sealed with VIF, but they received no fumigant.

Planting and cultural practices. The orchard trials involved planting conventionally grown, dormant, bare-root almond trees into plots that had received a preplant fumigation or control treatment (details below). Depending on the year and experiment, trees were planted from the last week of January to the first week of March, 3 to 4 months after fumigation. Immediately after planting, the tree stems were trimmed off at $0.6 \mathrm{~m}$ above the soil surface, lateral shoots were trimmed to stubs that retained one to two buds, and a plastic-impregnated white paper tube (10 $\mathrm{cm}$ diameter, $0.4 \mathrm{~m}$ high) was slipped over each tree stem for protection from sun and herbicides. The trees were irrigated by high-impact sprinklers; up to one irrigation per week was applied to meet crop evapotranspiration needs.

The microplot trials involved planting 2to 3-month-old Nemaguard peach seedlings into soil that had received pre-plant fumigation or control treatments (details below). The peach seeds were stratified for 2 months (8), planted and grown in a greenhouse for 2 to 3 months in trays of 2 $\times 2 \times 4 \mathrm{~cm}$ cells filled with UC potting mix (17), trimmed to a main stem height of 10 $\mathrm{cm}$, and transplanted into the microplots. Depending on the experiment, transplanting occurred on 3 June 2002, 9 April 2003, or 14 April 2004. The microplots were irrigated daily with 0.4 to 2.0 liters of water per microplot through a drip system and, starting 1 month after planting, fertilized monthly with $\left(\mathrm{NH}_{4}\right)_{2} \mathrm{SO}_{4}$ or $\mathrm{Ca}\left(\mathrm{NO}_{3}\right)_{2}$ ( 28 to $56 \mathrm{~kg} \mathrm{~N} /$ ha per fertilization). Irrigation amounts were increased and decreased according to soil moisture level, which was kept near field capacity. Weeds were controlled by regular hand pulling.

Effects of alternative fumigation treatments (experiments 1 to 8). Effects of pre-plant soil fumigation treatments on incidence and severity of RD were examined in five orchard trials (experiments 1 to 5 , in orchards 1,2 , and 3 introduced above) and three microplot trials (experiments 6 to 8, in the microplots near Parlier). Experiment 1 compared broadcast applications of MB (98:2 formulation, included 2\% CP, TriCal, Inc., Hollister, CA), CP (Tri-clor, TriCal, Inc.), and 1,3 dichloropropene (1,3-D) (Telone II, Dow Agrosciences, Indianapolis, IN), all at 400 $\mathrm{kg} / \mathrm{ha}$, and a nonfumigated control in orchard 1. Each treatment was applied to four replicate $19 \times 22 \mathrm{~m}$ plots in randomized complete blocks. Each plot was planted with three rows of six almond trees on Marianna 2624 rootstock; trees were 6.4 and $3.6 \mathrm{~m}$ apart between and within rows, respectively.

Experiments 2 to 5 evaluated pre-plant spot fumigation treatments applied to sites where planting holes were to be dug (i.e., planting sites) in orchards 1,2 , and 3 . Depending on the orchard, planting sites were 1.8 to $2.9 \mathrm{~m}$ apart within rows and $6.4 \mathrm{~m}$ apart between rows. Depending on the experiment, treatments included $\mathrm{MB}$ at 0.5 $\mathrm{kg}$ per planting site and two or more rates of iodomethane (IM), IM:CP (50:50, $\mathrm{wt} / \mathrm{wt}$, both referred to as formulations of Midas, Arysta LifeScience North America Corporation, Cary, NC), CP, 1,3-D, and 1,3-D:CP (61:35, Telone C35, DowAgrosciences, Indianapolis, IN), and a nonfumigated control. Each planting site received one Carmel almond tree on Marianna 2624 rootstock. In experiments 2 to 4 , there were 12 or 18 trees per treatment arranged in six randomized complete blocks. In experiment 5, there were five trees per treatment in a completely randomized design.

Experiments 6 to 8 examined effects of $\mathrm{CP}$ and MB (each at 425 and 3,040 kg/ha) and a nonfumigated control in the microplots. The treatments were arranged in 12 randomized complete blocks; each block had one replicate microplot per 
treatment. Three Nemaguard peach seedlings were planted per microplot.

Effects of different rootstocks (experiments 9 to 11). Experiments 9, 10, and 11 were conducted in orchards 1,2 , and 3 near Chico, respectively. In experiment 9, Carmel almond trees on rootstocks of Marianna 2624 and Lovell peach were planted in sites that had been spot fumigated with MB:CP (75:25, wt/wt, $0.5 \mathrm{~kg}$ per site) or CP $(0.5 \mathrm{~kg}$ per site) or left nonfumigated; there were 18 trees per factorial treatment combination, allocated evenly among six randomized complete blocks. Experiments 10 and 11 were similar to experiment 9, except that Nemaguard peach rootstock also was included, and there were 12 trees per treatment allocated evenly among six randomized complete blocks.

Disease assessment. In the orchard trials, effects of treatments on RD were assessed by measuring increases in trunk diameter and assigning disease ratings. The trunk diameters were measured at planting and in late summer or after completion of the growing season, during tree dormancy. Disease ratings were assigned in late August to mid-October using the following scale: $0=$ tree healthy aboveground (length of shoot growth normal for healthy replanted trees in region, no wilting, leaf discoloration, or defoliation); 1 = trees slightly stunted (i.e., shoots 20 to $30 \%$ shorter than normal), but otherwise appear healthy; $2=$ trees moderately stunted (i.e., shoots 40 to $50 \%$ shorter), exhibiting little or no wilting, leaf discoloration, or defoliation; $3=$ trees severely stunted (i.e., shoots $\geq 60 \%$ shorter) and/or exhibiting moderate wilting, defoliation, or leaf discoloration; $4=$ trees dying (i.e., regardless of size, tree severely wilted and defoliated and starting to dehydrate); $5=$ tree dead, i.e., all leaves that remain are necrotic, shoot epidermis wrinkled from dehydration. Near the end of the growing season, trees with shoots that reached a height of at least $1.2 \mathrm{~m}$ above the soil surface and had disease ratings of 0 to 2 were considered commercially acceptable; those that were shorter or had higher disease ratings were considered unacceptable.

To examine effects of RD on root length density, Carmel almond trees on Marianna 2624 and Lovell rootstocks were planted in February 2004 in CP-fumigated $(0.5 \mathrm{~kg}$ per planting site, applied in fall 2003) and nonfumigated control sites in orchards 2 and 3 , adjacent to areas used for experiments 3, 4, 10, and 11. The fumigation treatments were randomized in blocks containing one (orchard 3) or two (orchard 2) tree planting sites per fumigation treatment. The trees on Marianna 2624 and Lovell rootstocks were considered to be in separate experiments because their treatment blocks were grouped separately. On 20 October 2004, root systems were sampled from three randomly selected trees on each rootstock in each of the orchards. Each sample included the roots within a 60 -cm-diameter $\times 45$-cm-deep cylinder of soil centered around one almond tree's trunk. The roots and adhering soil were excavated with shovels, collected in plastic bags, and stored at $4^{\circ} \mathrm{C}$. The roots were gently washed free from the soil while being supported on a 2-mm mesh screen and blotted to remove free water. Roots that washed through the screen were collected and included in length analyses. An Epson 1640 XL scanner optimized for root system analyses by Regent Instruments, Inc. (Ste-Foy, QC, Canada) and WinRHIZO v.2004b software were used to determine the root length density in each sample. The "Regents simple scanner interface" was used with 800 dpi grayscale images specified, and the roots were spread on the scanner glass so that there was seldom overlap among them. Exclusion regions were defined to eliminate contributions of debris.

For experiments in microplots, effects on $\mathrm{RD}$ were assessed by weighing plant tops (i.e., stems and shoots) twice during the growing season. On each date, the tops from four randomly selected blocks were weighed. Effects of RD on root length densities of Nemaguard peach plants were determined in the 2004 microplots (experiment 8). The first week of November 2004, 13-cm-diameter $\times 30$-cm-deep cores of soil and the enclosed roots were collected from four randomly selected blocks. Each soil-root core was centered around the stem of one peach plant, and two cores were collected per microplot. The root samples were processed and analyzed as described above.

Examining plant-parasitic nematode populations. Samples of soil and roots were collected periodically from trees in the orchard and microplot trials and assayed for plant-parasitic nematodes. In orchard 1, the samples were collected on 11 November 2002 from the trees in three randomly selected blocks of experiment 9; a $500-\mathrm{cm}^{3}$ sample of soil and roots was collected from depths of 5 to $45 \mathrm{~cm}$ below the soil surface within $30 \mathrm{~cm}$ of each tree's trunk and stored at $5^{\circ} \mathrm{C}$ for nematode extraction. A sieving/sugar flotation/ centrifugation protocol with a 500-mesh sieve ( $25 \mu \mathrm{m}$ opening) was used to extract nematodes from the samples (12). The extracted nematodes were identified and counted under a microscope. In orchards 2 and 3, samples were collected in October 2003 by excavating almond trees on Marianna 2624 rootstock; four trees were sampled per treatment in randomized complete blocks of nonfumigated and CPfumigated $(0.5 \mathrm{~kg}$ per planting site $)$ plots. The plots had been established solely for sampling purposes and were adjacent to areas used for experiments $3,4,10$, and 11 . At least $20 \mathrm{~g}$ of fine roots (diameter $\leq 3$ $\mathrm{mm}$ ) and $500 \mathrm{~cm}^{3}$ of adjacent soil (5 to 45 $\mathrm{cm}$ soil depth, $\leq 30 \mathrm{~cm}$ from the tree trunk) were collected from each of the trees and stored at $5^{\circ} \mathrm{C}$. The soil was assayed for plant-parasitic nematodes as described above, and the roots were assayed using the mist chamber protocol (11). In orchard 3, the sampling and assay procedures used in 2003 were repeated in 2004 using an additional four blocks of single-tree CPfumigated and control plots. The plots had been planted with almond trees on Marianna 2624 rootstock in March 2004 after pre-plant fumigation in November 2003.

Each microplot trial was sampled for nematodes on one or two occasions (i.e., 13 August and 25 September for the 2002 trial, 14 August for 2003, and 24 October for 2004). On each occasion, the microplots in four randomly selected replicate blocks were sampled. A soil sampling tube $(2 \times 45 \mathrm{~cm})$ was used to collect multiple cores of soil and roots, totaling 500 $\mathrm{cm}^{3}$ per microplot, from 0 to $45 \mathrm{~cm}$ soil depth within $20 \mathrm{~cm}$ of the experimental peach plants. Nematodes were extracted from the soil by flotation and counted as described above. In addition, $20 \mathrm{~g}$ of roots were collected from each microplot sampled on 24 October 2004 and processed by the mist chamber protocol.

Data analyses. All plant growth and health data were subjected to analysis of variance (ANOVA) using PROC MIXED of SAS software (SAS, Release 9.1, Cary, NC). Data from subsample trees (i.e., those given the same treatment within a microplot or block) were averaged and disease ratings were transformed to square root values before ANOVA. Block was specified as a random effect in experiments with randomized complete block designs. Confidence intervals $(95 \%)$ were generated to facilitate mean separation. Although nontransformed disease rating means are presented, the associated mean separations are based on $95 \%$ confidence intervals determined from the square-root-transformed data. For all tree performance data, the Levine's test option of PROC ANOVA (SAS, Release 9.1) was used to test for homogeneity of variance. To accommodate variance heterogeneity, the "vargrp" option of PROC MIXED was used to calculate variances and $95 \%$ confidence intervals separately among treatment groups with dissimilar variance.

\section{RESULTS}

Foliar symptoms of RD and effects of alternative fumigation treatments (experiments 1 to 8). The onset and progress of aboveground symptoms of RD were qualitatively similar in each orchard trial with almond trees on Marianna 2624 rootstock (experiments 1 to 5). Until April, regardless of experiment, the trees in nonfumigated plots generally grew well, appeared healthy, and were not clearly distinguishable from those in fumigated plots. However, in May or June, the trees in con- 
trol plots suffered a marked decline in the rate of shoot elongation, and many of them exhibited chlorosis, wilting, and defoliation. The trees in plots treated with effective fumigants remained healthy and continued rapid shoot growth.

Some of the pre-plant fumigation treatments had significant positive impacts on tree trunk diameters, disease ratings, and tree height in each of the orchard fumigation trials with almond on Marianna 2624 rootstock (experiments 1 to 5; Tables 1 and 2; Fig. 1) $(P<0.0001$ to 0.0012$)$. In experiment 1 , which involved broadcast shank applications of $\mathrm{MB}, \mathrm{CP}$, and 1,3-D at $400 \mathrm{~kg} / \mathrm{ha}$ in orchard 1 , only the $\mathrm{CP}$

Table 1. Effects of broadcast pre-plant soil fumigation treatments applied through tractor-mounted shanks on growth of almond trees on Marianna 2624 rootstock in experiment 1, orchard 1, near Chico, $\mathrm{CA}$

\begin{tabular}{|c|c|c|c|c|}
\hline \multicolumn{2}{|c|}{ Pre-plant treatment ${ }^{y}$} & \multicolumn{3}{|c|}{ Tree performance in first growing season ${ }^{z}$} \\
\hline Fumigant & $\begin{array}{c}\text { Rate of } \\
\text { application } \\
\text { (kg/ha) }\end{array}$ & $\begin{array}{c}\text { Tree height } \\
\text { (m) }\end{array}$ & $\begin{array}{c}\text { Increase in } \\
\text { trunk diameter } \\
(\mathbf{m m})\end{array}$ & $\begin{array}{c}\text { Disease } \\
\text { rating }\end{array}$ \\
\hline Control & None & $1.0 \mathrm{a}$ & $1 \mathrm{a}$ & $3.4 \mathrm{a}$ \\
\hline $\mathrm{MB}$ & 400 & $1.2 \mathrm{a}$ & $4 \mathrm{~b}$ & $2.1 \mathrm{~b}$ \\
\hline $\mathrm{CP}$ & 400 & $1.7 \mathrm{~b}$ & $10 \mathrm{c}$ & $0.3 \mathrm{c}$ \\
\hline $1,3-\mathrm{D}$ & 400 & $1.1 \mathrm{a}$ & $2 \mathrm{a}$ & $2.9 \mathrm{a}$ \\
\hline
\end{tabular}

${ }^{y}$ All fumigants, methyl bromide (MB), chloropicrin (CP), and 1,3-dichloropropene (1,3-D), were injected into soil by tractor-mounted shanks with nozzles spaced $50 \mathrm{~cm}$ apart at a soil depth of 40 to $50 \mathrm{~cm}$. MB included $2 \% \mathrm{CP}$.

${ }^{\mathrm{z}}$ Trees planted 22 January 2001. Tree height and disease ratings determined 13 August 2001. Increase in trunk diameter measured from time of planting to 13 August 2001. Disease rating based on a scale of $0=$ healthy tree, $5=$ dead tree, and 1,2,3, and 4 were progressive increments of disease within the extremes. Means within a column and without letters in common are significantly different according to $95 \%$ confidence intervals.

treatment was effective (Table 1). In the first growing season after planting, trees in the control plots increased little in trunk diameter (mean increase $1 \mathrm{~mm}$ ) or tree height (mean tree height $1.0 \mathrm{~m}$ ). The control trees developed high disease ratings (mean 3.4), and only 3\% of them were commercially acceptable. The MB treatment slightly decreased the disease ratings and slightly increased trunk growth (Table 1 ), but only $42 \%$ of the trees were commercially acceptable. The $\mathrm{CP}$ treatment increased trunk diameter growth and decreased disease ratings by a factor of approximately 10 compared with the control, and $96 \%$ of the trees in CP plots were commercially acceptable. The 1,3-D treatment did not significantly improve tree growth or health (Table 1), and only $8 \%$ of the trees were acceptable.

In experiment 2, which involved spot fumigation of tree planting sites in orchard 1 , greatest tree growth and lowest disease ratings occurred following $\mathrm{CP}$ at 0.2 to 0.5 $\mathrm{kg}$ per planting site, but $\mathrm{CP}$ at $0.9 \mathrm{~kg}$ per planting site caused phytotoxicity (Table 2). Pre-plant spot fumigation with $\mathrm{MB}$ and $1,3-\mathrm{D}$ at 0.5 and $0.8 \mathrm{~kg}$ per tree site, respectively, resulted in trunk diameter

Table 2. Effects of pre-plant soil fumigation treatments applied to planting sites through a hand-held probe on growth of almond trees on Marianna 2624 rootstock near Chico, CA

\begin{tabular}{|c|c|c|c|c|c|c|c|c|c|}
\hline \multirow{3}{*}{$\begin{array}{l}\text { Experiment } \\
\text { no. }\end{array}$} & & & \multicolumn{7}{|c|}{ Tree growth and health parameters at end of indicated growing season ${ }^{z}$} \\
\hline & \multicolumn{2}{|c|}{ Pre-plant treatment ${ }^{\mathbf{y}}$} & Height (m) & \multicolumn{3}{|c|}{ Increase in trunk diameter $(\mathrm{mm})$} & \multicolumn{3}{|c|}{ Disease rating } \\
\hline & Fumigant & $\mathrm{kg} / \mathrm{site}$ & First & First & Second & Third & First & Second & Third \\
\hline \multirow[t]{6}{*}{2} & Control & 0.0 & $1.4 \mathrm{a}$ & $8 \mathrm{a}$ & -- & -- & $2.0 \mathrm{a}$ & -- & -- \\
\hline & MB & 0.5 & $1.8 \mathrm{ab}$ & $12 \mathrm{ab}$ & -- & -- & $1.0 \mathrm{ab}$ & -- & -- \\
\hline & 1,3-D & 0.8 & $1.8 \mathrm{ab}$ & $12 \mathrm{ab}$ & -- & -- & $1.0 \mathrm{ab}$ & -- & -- \\
\hline & $\mathrm{CP}$ & 0.2 & $2.0 \mathrm{~b}$ & $17 \mathrm{~b}$ & -- & -- & $0.4 \mathrm{~b}$ & -- & -- \\
\hline & $\mathrm{CP}$ & 0.5 & $2.0 \mathrm{~b}$ & $17 \mathrm{~b}$ & -- & -- & $0.4 \mathrm{~b}$ & -- & -- \\
\hline & $\mathrm{CP}$ & 0.9 & $1.6 \mathrm{ab}$ & $12 \mathrm{ab}$ & -- & -- & $1.7 \mathrm{ab}$ & -- & -- \\
\hline \multirow[t]{10}{*}{3} & Control & 0.0 & $1.0 \mathrm{a}$ & $6 \mathrm{a}$ & $16 \mathrm{a}$ & $31 \mathrm{a}$ & $3.3 \mathrm{a}$ & $2.1 \mathrm{a}$ & $2.0 \mathrm{a}$ \\
\hline & MB & 0.5 & $1.7 \mathrm{bc}$ & $18 \mathrm{bc}$ & $47 \mathrm{~b}$ & $63 \mathrm{ab}$ & $1.0 \mathrm{~b}$ & $0.0 \mathrm{~b}$ & $0.4 \mathrm{~b}$ \\
\hline & $\mathrm{CP}$ & 0.2 & $2.0 \mathrm{c}$ & $25 \mathrm{~d}$ & $54 \mathrm{~b}$ & $78 c$ & $0.3 \mathrm{~b}$ & $0.0 \mathrm{~b}$ & $0.0 \mathrm{~b}$ \\
\hline & $\mathrm{CP}$ & 0.5 & $1.9 \mathrm{bc}$ & $23 \mathrm{bcd}$ & $56 \mathrm{~b}$ & $80 \mathrm{c}$ & $0.4 \mathrm{~b}$ & $0.0 \mathrm{~b}$ & $0.0 \mathrm{~b}$ \\
\hline & IM:CP & 0.2 & $1.9 \mathrm{bc}$ & $22 \mathrm{bcd}$ & $55 \mathrm{~b}$ & $77 \mathrm{c}$ & $0.3 \mathrm{~b}$ & $0.1 \mathrm{~b}$ & $0.0 \mathrm{~b}$ \\
\hline & IM:CP & 0.5 & $1.9 \mathrm{bc}$ & $21 \mathrm{bcd}$ & $47 \mathrm{~b}$ & $75 \mathrm{bc}$ & $0.7 \mathrm{~b}$ & $0.0 \mathrm{~b}$ & $0.3 \mathrm{~b}$ \\
\hline & $1,3-\mathrm{D}$ & 0.2 & $1.6 \mathrm{~b}$ & $17 \mathrm{~b}$ & $45 \mathrm{~b}$ & $70 \mathrm{bc}$ & $1.2 \mathrm{~b}$ & $0.0 \mathrm{~b}$ & $0.0 \mathrm{~b}$ \\
\hline & 1,3-D & 0.5 & $1.7 \mathrm{bc}$ & $20 \mathrm{bcd}$ & $50 \mathrm{~b}$ & $74 \mathrm{bc}$ & $0.7 \mathrm{~b}$ & $0.0 \mathrm{~b}$ & $0.0 \mathrm{~b}$ \\
\hline & 1,3-D:CP & 0.2 & $1.7 \mathrm{bc}$ & $20 \mathrm{bcd}$ & $51 \mathrm{~b}$ & $71 \mathrm{bc}$ & $0.9 \mathrm{~b}$ & $0.0 \mathrm{~b}$ & $0.0 \mathrm{~b}$ \\
\hline & $1,3-\mathrm{D}: \mathrm{CP}$ & 0.5 & $1.9 \mathrm{bc}$ & $24 \mathrm{~cd}$ & $53 \mathrm{~b}$ & $76 \mathrm{c}$ & $0.3 \mathrm{~b}$ & $0.0 \mathrm{~b}$ & $0.0 \mathrm{~b}$ \\
\hline \multirow[t]{12}{*}{4} & Control & 0.0 & $1.2 \mathrm{a}$ & $3 \mathrm{a}$ & $19 \mathrm{a}$ & $40 \mathrm{a}$ & $3.5 \mathrm{a}$ & $1.0 \mathrm{a}$ & $0.0 \mathrm{a}$ \\
\hline & MB & 0.5 & $1.6 \mathrm{~b}$ & $11 \mathrm{~b}$ & $34 \mathrm{bc}$ & $60 \mathrm{bc}$ & $0.8 \mathrm{bc}$ & $0.0 \mathrm{~b}$ & $0.0 \mathrm{a}$ \\
\hline & $\mathrm{CP}$ & 0.2 & $2.0 \mathrm{~d}$ & $17 \mathrm{e}$ & $39 \mathrm{bc}$ & $63 \mathrm{bc}$ & $0.1 \mathrm{~d}$ & $0.0 \mathrm{~b}$ & $0.0 \mathrm{a}$ \\
\hline & $\mathrm{CP}$ & 0.5 & $2.0 \mathrm{~d}$ & $17 \mathrm{e}$ & $36 \mathrm{bc}$ & $66 c$ & $0.3 \mathrm{~cd}$ & $0.5 \mathrm{~b}$ & $0.0 \mathrm{a}$ \\
\hline & IM & 0.2 & $2.0 \mathrm{~d}$ & $12 b c$ & $36 \mathrm{bc}$ & $63 \mathrm{bc}$ & $0.1 \mathrm{~d}$ & $0.1 \mathrm{~b}$ & $0.0 \mathrm{a}$ \\
\hline & IM & 0.5 & $2.0 \mathrm{~d}$ & 14 bcde & $36 \mathrm{bc}$ & $62 \mathrm{bc}$ & $0.2 \mathrm{~cd}$ & $0.0 \mathrm{~b}$ & $0.0 \mathrm{a}$ \\
\hline & IM:CP & 0.2 & $1.8 \mathrm{bcd}$ & $16 \mathrm{cde}$ & $40 c$ & $65 \mathrm{c}$ & $0.8 \mathrm{bcd}$ & $0.0 \mathrm{~b}$ & $0.0 \mathrm{a}$ \\
\hline & IM:CP & 0.5 & $1.9 \mathrm{bcd}$ & $16 \mathrm{de}$ & $39 \mathrm{bc}$ & $65 \mathrm{c}$ & $0.4 \mathrm{bcd}$ & $0.0 \mathrm{~b}$ & $0.0 \mathrm{a}$ \\
\hline & $1,3-\mathrm{D}$ & 0.2 & $1.7 \mathrm{bc}$ & $13 \mathrm{bcd}$ & $32 \mathrm{~b}$ & $55 \mathrm{~b}$ & $0.8 \mathrm{~b}$ & $0.4 \mathrm{~b}$ & $0.0 \mathrm{a}$ \\
\hline & $1,3-\mathrm{D}$ & 0.5 & $2.0 \mathrm{~d}$ & $15 \mathrm{cde}$ & $37 \mathrm{bc}$ & $62 \mathrm{bc}$ & $0.3 \mathrm{bcd}$ & $0.0 \mathrm{~b}$ & $0.0 \mathrm{a}$ \\
\hline & 1,3-D:CP & 0.2 & $1.9 \mathrm{~cd}$ & 14 bcde & $36 \mathrm{bc}$ & $60 \mathrm{bc}$ & $0.3 \mathrm{bcd}$ & $0.3 \mathrm{~b}$ & $0.0 \mathrm{a}$ \\
\hline & 1,3-D:CP & 0.5 & $1.9 \mathrm{~cd}$ & $15 \mathrm{cde}$ & $38 \mathrm{bc}$ & $64 c$ & $0.3 \mathrm{bcd}$ & $0.0 \mathrm{~b}$ & $0.0 \mathrm{a}$ \\
\hline
\end{tabular}

${ }^{y}$ All fumigants, methyl bromide (MB), chloropicrin (CP), iodomethane (IM), IM:CP (50:50 wt/wt), 1,3-dichloropropene (1,3-D), and 1,3-D:CP (61:35 $\mathrm{wt} / \mathrm{wt}$, Telone C35), were injected by a hand-held probe at one point at a soil depth of 45 to $50 \mathrm{~cm}$ in the center of sites where trees were to be planted.

${ }^{z}$ Tree height was measured at the end of the growing season (mid-October to early December, depending on experiment). Increases in trunk diameter were determined by measuring tree trunks near the end of the indicated growing seasons (late October to early February, depending on experiment) and calculating the net increase in diameter from time of planting. Disease ratings were made near the end of the indicated growing seasons (late August to midOctober) and based on a scale of $0=$ healthy tree, $5=$ dead tree, and 1,2,3, and 4 were progressive increments of disease within the extremes. Means within a column and experiment and without letters in common are significantly different according to $95 \%$ confidence intervals. 
growth and disease ratings intermediate between the effective $\mathrm{CP}$ treatments and the control. In the control and phytotoxic $\mathrm{CP}$ treatments, 70 and $65 \%$ of the trees were acceptable, respectively, whereas 85 to $93 \%$ of the trees were acceptable in the other fumigated plots.

In experiments 3 and 4, which involved spot fumigation of planting sites in orchards 2 and 3, respectively, the control trees in nonfumigated soil grew little and developed high disease ratings in the first growing season (Table 2). The control trees showed only partial recovery in the second and third growing seasons after planting. Pre-plant fumigation with $\mathrm{MB}$ at $0.5 \mathrm{~kg}$ per planting site significantly increased tree trunk diameters and tree heights and lowered disease ratings in the first two growing seasons compared with the control. All the other pre-plant fumigation treatments (i.e., CP, IM, IM:CP, 1,3-D, 1,3-D:CP; 0.2 to $0.5 \mathrm{~kg}$ per tree site) improved tree performance to similar or greater extents through the third year after planting compared with the MB treatment.

In experiment 5 , all rates of $\mathrm{CP}(0.12$, $0.24,0.45$, and $0.9 \mathrm{~kg}$ per planting site) resulted in large and equivalent increases in tree trunk growth compared with the control (Fig. 1A). The treatment benefits persisted and were manifested in 10-fold increases in marketable nut kernel yields in the first harvest, which occurred in the fall of the third growing season (Fig. 1A and $\mathrm{B}$ ).

Symptoms of RD developed on Nemaguard peach rootstock in the nonfumigated microplots within 2 months after planting (experiments 6 to 8 ). The control seedlings developed relatively small, chlorotic leaves with tip necrosis and boat-shaped deformation. Some of the control plants suffered partial defoliation, but few died. Effects of the pre-plant fumigation treatments were highly significant in each microplot experiment $(P<0.0001$; Fig. $2 \mathrm{~A}$ to $\mathrm{C})$. The low rate of MB $(425 \mathrm{~kg} / \mathrm{ha})$ had no significant effect on the plant top weights, whereas the same rate of $\mathrm{CP}$ increased shoot weights by 2.5 to $15.5 \times$ compared with the control, depending on the experiment and date of measurement. Both fumigants were effective at the high rate $(3,040 \mathrm{~kg} / \mathrm{ha})$ and increased shoot weights by 3.5 to $21 \times$ compared with the control (Fig. 2). The favorable growth responses to fumigation became evident by early summer and persisted through the growing season.

Effects of alternative rootstocks. In experiment 9, first-season tree height, trunk diameter growth, and disease ratings were affected significantly by rootstock $(P$ $=0.0003$ to 0.007$)$ and fumigation treatments $(P<0.0001)$, but there was no significant interaction between the factors $(P$ $=0.18$ to 0.31 ) (Table 3 ). In nonfumigated plots, almond trees on Lovell rootstock grew taller than those on Marianna 2624 rootstock (Table 3). Nevertheless, without pre-plant fumigation, tree performance was suboptimal on either rootstock. Preplant fumigation with either $\mathrm{MB}: \mathrm{CP}$ or $\mathrm{CP}$ $(0.5 \mathrm{~kg}$ per planting site) resulted in large increases in trunk diameters and tree heights for both rootstocks.

Results of experiments 10 and 11 were combined due to lack of significant experiment $\times$ rootstock and experiment $\times$ rootstock $\times$ fumigation interaction $(P=$ 0.13 to 0.92 ) for all variables except disease ratings in the third growing season (Table 3; experiments 10 and 11). The ANOVA could not be completed with the latter variable due to a large number of zero disease ratings. Rootstock and fumigation had significant main effects for all variables in the first and second growing seasons $(P<0.0001$ to 0.03$)$. Interaction of rootstock $\times$ fumigation was significant only for trunk diameter increases and disease ratings in the second growing season $(P<0.0001$ to 0.0003$)$. In nonfumigated soil, almond trees on Lovell or Nemaguard peach rootstocks grew taller than those on Marianna 2624 rootstock for the first season (Table 3). Similarly, in the first and second growing seasons, trees on the peach rootstocks generally produced greater trunk diameter increases than those on Marianna 2624 roots. Nevertheless, without pre-plant fumigation, trees grew suboptimally regardless of rootstock. Pre-

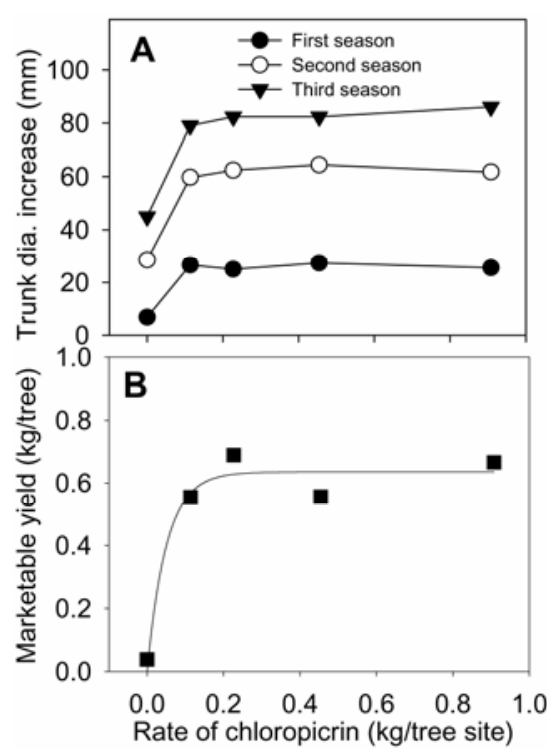

Fig. 1. Effect of different pre-plant doses of chloropicrin, injected at planting sites at soil depth of 45 to $50 \mathrm{~cm}$, on growth of almond trees on Marianna 2624 rootstock in experiment 5. A, increases in trunk diameter by the end of indicated growing seasons after planting; and $\mathbf{B}$, marketable nut (kernel) yield from the first harvest at the end of the third growing season. For each line, mean growth increases and yields were significantly greater in fumigated plots than in nonfumigated plots (based on $95 \%$ confidence intervals). Nut yield means were fit to the line described by $y=0.63\left(1-e^{-19.67}\right)$ with an $r^{2}$ value of 0.95 . plant fumigation with either $\mathrm{MB}: \mathrm{CP}$ or $\mathrm{CP}$ $(0.5 \mathrm{~kg}$ per planting site) resulted in large, significant increases in tree trunk diameters and heights for all rootstocks. The benefit to trunk diameters from pre-plant soil fumigation persisted through the duration of experiments.

Effects of pre-plant fumigation on root length density. Pre-plant soil fumigation with $\mathrm{CP}$ increased length density of fine roots $(\leq 1 \mathrm{~mm}$ diameter $)$ on almond trees in orchards 2 and 3 (Fig. 3). For the trees on Lovell rootstock, results from the two orchards were combined due to lack of significant interaction of orchard location with other factors $(P=0.10$, Fig. $3 \mathrm{~A})$. On Lovell, the length densities were affected by significant interaction between preplant fumigation treatment and root diameter class $(P<0.0001)$. The greatest length density occurred in roots $\leq 0.5 \mathrm{~mm}$, and pre-plant fumigation with $\mathrm{CP}$ more than doubled the length density in this category. For the trees on Marianna 2624 rootstock, there was a significant three-way interaction among fumigation treatment, orchard location, and root diameter class $(P<$ 0.0001); therefore the results are presented by orchard (Fig. 3B and C). In orchard 2, most root length occurred in roots $\leq 0.5$

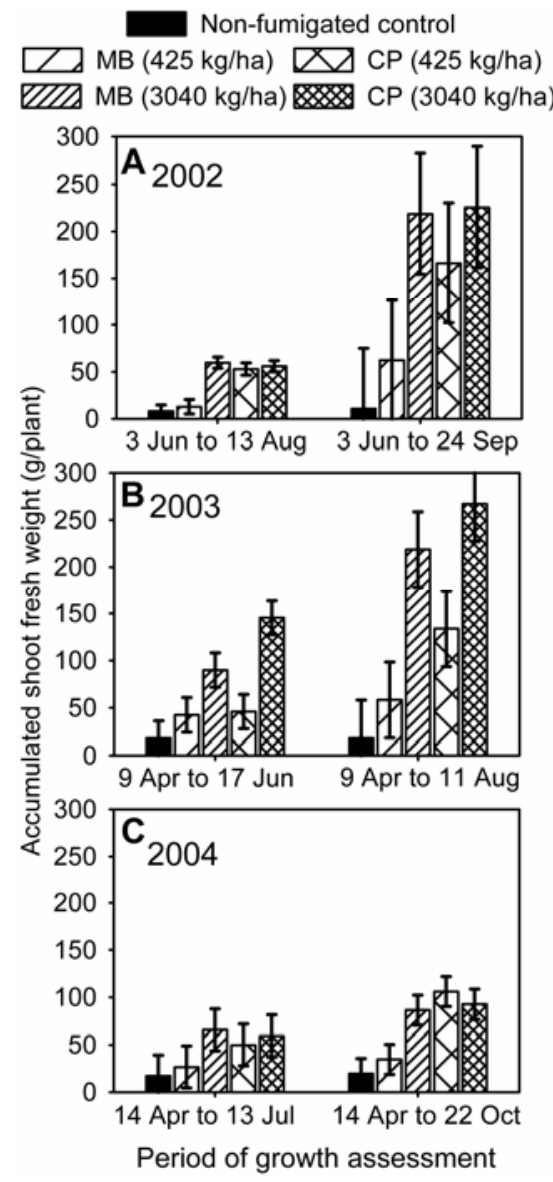

Fig. 2. Effect of pre-plant doses of methyl bromide (MB) and chloropicrin (CP), injected at soil depth of $30 \mathrm{~cm}$, on growth of Nemaguard peach seedlings in microplots near Parlier, CA. Vertical bars are $95 \%$ confidence intervals. 
$\mathrm{mm}$ diameter, and trees in $\mathrm{CP}$ plots had an average of approximately seven times more total root length compared with the control (Fig. 3B). In orchard 3, the results were similar, except $\mathrm{CP}$ only significantly increased the length density of roots $\leq 0.5$ $\mathrm{mm}$ diameter, and the trees in fumigated soil had approximately twice the root length density of trees in nonfumigated soil (Fig. 3C).

In Nemaguard peach root samples from microplots, both of the CP treatments (425 and $3,040 \mathrm{~kg} / \mathrm{ha}$ ) significantly increased root length densities in the 0 to $0.5 \mathrm{~mm}$ diameter class compared with the other treatments. Samples from both the MB treatments had root length densities equal to or smaller than the control (Fig. 4).

Lack of significant populations of plant-parasitic nematodes. In orchard 1, experiment 9, the sugar flotation method extracted 0 to 1 lesion nematode (Pratylenchus sp.) per $250 \mathrm{~cm}^{3}$ of soil, regardless of pre-plant fumigation treatment. No other plant-parasitic nematodes were detected. Similarly, no plant-parasitic nematodes were detected by sugar flotation or mist chamber extraction from soil and root samples collected from orchard 2 in 2003 and 2004 and orchard 3 in 2003.

In the 2002 microplots, numerically significant populations of the pin nematode (Paratylenchus sp.) were detected in samples from the nonfumigated treatment, but there was no clear association between the populations and incidence or severity of RD. An average of 424 and 122 pin nematodes per $250 \mathrm{~cm}^{3}$ were extracted by sugar flotation from nonfumigated plot samples collected on 14 August and 24 September, respectively. Fewer than 8 pin nematodes per $250 \mathrm{~cm}^{3}$ were detected in the other treatments in 2002, and none were in plots fumigated with $\mathrm{MB}$ at $425 \mathrm{~kg} / \mathrm{ha}$. The lesion nematode (Pratylenchus sp.) was detected in only one control plot ( 2 per 250 $\mathrm{cm}^{3}$; 14 August 2002).

Similarly, in 2003 and 2004 microplots, there was no evidence for contributions of plant-parasitic nematodes to RD. In 2003, lesion nematode was not detected, and a mean of three pin nematodes per $250 \mathrm{~cm}^{3}$ was extracted by sugar flotation from the controls. No other plant-parasitic nematodes were detected. In 2004, one of the four nonfumigated plots had six lesion nematodes per $20 \mathrm{~g}$ roots and 10 lesion nematodes per $250 \mathrm{~cm}^{3}$ soil, but no other plant-parasitic nematodes were detected.

\section{DISCUSSION}

We have characterized symptoms of RD on almond in the Central Valley of California and determined that the disease is not associated with nematode infestation, that it seriously impacts almond on three important rootstocks, and that it can be prevented by pre-plant fumigation with several $\mathrm{MB}$ alternatives. The results are important to California peach production as well as almond production because the crops have their most prevalent rootstocks in common (i.e., Nemaguard and Lovell peach) (8) and are grown in overlapping areas of the state. At sites severely affected by $\mathrm{RD}$, broadcast and spot fumigation treatments with $\mathrm{CP}$ consistently prevented the disease and often were more effective than comparable treatments with $\mathrm{MB}$. Also, spot fumigation with 1,3-D, IM, or combinations of them with $\mathrm{CP}$, prevented the disease and matched or exceeded the efficacy of spot treatments with MB. To our knowledge, this is the first detailed report of RD on almond and relative effectiveness of the tested fumigants for managing the disease.

The RD seriously compromised tree performance on all three rootstocks tested (Marianna 2624, and Lovell and Nemaguard peach). For some of the performance variables, the disease impact was less on the peach rootstocks than on Marianna 2624 , but our results indicate that use of peach rootstock, without effective preplant fumigation, is not an adequate RD control strategy for the disease on almond. Nevertheless, further investigation of almond rootstock tolerance to RD is warranted. In an Italian study, peach and nectarine trees were less affected by a replant disease on rootstocks of Prunus persica $\times$ $P$. dulcis or $P$. persica $\times P$. davidiana than on rootstocks of $P$. persica or $P$. domestica (6). Almond cultivars are compatible with rootstocks of $P$. persica $\times P$. dulcis (13).

The effectiveness of the spot fumigation treatments at planting sites demonstrated that RD can be prevented without applying fumigants to entire areas or wide strips of land. This is important because a reduction of treated area potentially reduces environmental impact and fumigant costs. In repeated experiments, 0.2 and $0.5 \mathrm{~kg} \mathrm{CP}$ per planting site were equally effective and consistently prevented RD, and in experiment $5,0.12 \mathrm{~kg}$ per planting site was also effective. At commercial planting densities of 200 to 350 trees per ha, the use of 0.2 $\mathrm{kg}$ of $\mathrm{CP}$ per planting site requires 40 to 70

Table 3. Effects of rootstocks and pre-plant soil fumigation treatments applied to planting sites through a hand-held probe on growth of almond trees near Chico, CA

\begin{tabular}{|c|c|c|c|c|c|c|c|c|c|c|}
\hline \multirow{3}{*}{$\begin{array}{l}\text { Experiment } \\
\text { no. }\end{array}$} & \multirow[b]{3}{*}{ Rootstock } & & & \multicolumn{7}{|c|}{ Tree growth and health parameters at end of indicated growing seasons } \\
\hline & & \multicolumn{2}{|c|}{ Pre-plant treatment ${ }^{y}$} & \multirow{2}{*}{$\frac{\text { Height }(\mathbf{m})}{\text { First }}$} & \multicolumn{3}{|c|}{ Increase in trunk diameter $(\mathbf{m m})^{\mathrm{z}}$} & \multicolumn{3}{|c|}{ Disease rating } \\
\hline & & Fumigant & kg/site & & First & Second & Third & First & Second & Third \\
\hline \multirow{6}{*}{9} & \multirow{3}{*}{ Marianna 2624} & Control & 0 & $1.1 \mathrm{a}$ & $4 \mathrm{a}$ & -- & -- & $2.9 \mathrm{a}$ & -- & -- \\
\hline & & MB:CP & 0.5 & $1.9 \mathrm{~cd}$ & $15 \mathrm{~b}$ & -- & -- & $0.4 \mathrm{~b}$ & -- & -- \\
\hline & & $\mathrm{CP}$ & 0.5 & $1.9 \mathrm{~cd}$ & $14 \mathrm{~b}$ & -- & -- & $0.6 \mathrm{~b}$ & -- & -- \\
\hline & \multirow[t]{3}{*}{ Lovell } & Control & 0 & $1.6 \mathrm{~b}$ & $7 \mathrm{a}$ & -- & -- & $1.7 \mathrm{a}$ & -- & -- \\
\hline & & $\mathrm{MB}: \mathrm{CP}$ & 0.5 & $2.1 \mathrm{~cd}$ & $15 \mathrm{~b}$ & -- & -- & $0.3 \mathrm{~b}$ & -- & -- \\
\hline & & $\mathrm{CP}$ & 0.5 & $2.3 \mathrm{~d}$ & $17 \mathrm{~b}$ & -- & -- & $0.0 \mathrm{~b}$ & -- & -- \\
\hline \multirow[t]{9}{*}{10,11} & \multirow[t]{3}{*}{ Marianna 2624} & Control & 0 & $1.1 \mathrm{a}$ & $4 \mathrm{a}$ & $23 \mathrm{a}$ & $39 a$ & $3.4 \mathrm{a}$ & $1.3 \mathrm{a}$ & $0.8 \mathrm{a}$ \\
\hline & & MB:CP & 0.5 & $1.9 \mathrm{c}$ & $20 \mathrm{~cd}$ & $47 \mathrm{c}$ & $68 \mathrm{~b}$ & $0.6 \mathrm{c}$ & $0.0 \mathrm{~b}$ & $0.3 \mathrm{a}$ \\
\hline & & $\mathrm{CP}$ & 0.5 & $2.0 \mathrm{~cd}$ & $22 \mathrm{~cd}$ & $52 \mathrm{c}$ & $76 \mathrm{~b}$ & $0.3 \mathrm{c}$ & $0.0 \mathrm{~b}$ & $0.0 \mathrm{a}$ \\
\hline & \multirow[t]{3}{*}{ Lovell } & Control & 0 & $1.5 \mathrm{~b}$ & $9 \mathrm{~b}$ & $33 \mathrm{~b}$ & $57 \mathrm{a}$ & $2.1 \mathrm{~b}$ & $0.1 \mathrm{~b}$ & $0.0 \mathrm{a}$ \\
\hline & & MB:CP & 0.5 & $2.3 \mathrm{~d}$ & $21 \mathrm{~cd}$ & $48 \mathrm{c}$ & $73 \mathrm{~b}$ & $0.1 \mathrm{c}$ & $0.0 \mathrm{~b}$ & $0.0 \mathrm{a}$ \\
\hline & & $\mathrm{CP}$ & 0.5 & $2.2 \mathrm{~d}$ & $22 \mathrm{~d}$ & $51 \mathrm{c}$ & $76 \mathrm{~b}$ & $0.2 \mathrm{c}$ & $0.0 \mathrm{~b}$ & $0.0 \mathrm{a}$ \\
\hline & \multirow[t]{3}{*}{ Nemaguard } & Control & 0 & $1.4 \mathrm{~b}$ & $7 \mathrm{a}$ & $30 \mathrm{~b}$ & $54 \mathrm{a}$ & $2.6 \mathrm{ab}$ & $0.3 \mathrm{~b}$ & $0.0 \mathrm{a}$ \\
\hline & & MB:CP & 0.5 & $2.0 \mathrm{~cd}$ & $18 \mathrm{c}$ & $46 \mathrm{c}$ & $71 \mathrm{~b}$ & $0.3 \mathrm{c}$ & $0.0 \mathrm{~b}$ & $0.0 \mathrm{a}$ \\
\hline & & $\mathrm{CP}$ & 0.5 & $2.2 \mathrm{~d}$ & $20 \mathrm{~cd}$ & $46 \mathrm{c}$ & $71 \mathrm{~b}$ & $0.2 \mathrm{c}$ & $0.0 \mathrm{~b}$ & $0.0 \mathrm{a}$ \\
\hline
\end{tabular}

${ }^{y}$ Methyl bromide + chloropicrin (MB:CP, 75\% MB 25\% CP) and chloropicrin (CP) were injected by a hand-held probe at a soil depth of 45 to $50 \mathrm{~cm}$ in the center of sites where trees were to be planted.

${ }^{\mathrm{z}}$ Tree height was measured at the end of the growing season (mid-October to early December, depending on experiment). Increases in trunk diameter were determined by measuring tree trunks near the end of the indicated growing seasons (late October to early February, depending on experiment) and calculating the net increase in diameter from time of planting. Disease ratings were made near the end of the indicated growing seasons (late August to mid-October) based on a scale of $0=$ healthy tree, $5=$ dead tree, and 1,2,3, and 4 were progressive increments of disease within the extremes. Means within a column and experiment group (i.e., experiment 9 or experiments 10,11) and without letters in common are significantly different according to $95 \%$ confidence intervals. 
$\mathrm{kg} / \mathrm{ha}$ (orchard basis), which is substantially less than the amount required for a typical broadcast treatment with $\mathrm{CP}$ (approximately $336 \mathrm{~kg} / \mathrm{ha}$ ).

Using the $60-\mathrm{cm}$-diameter tractorpowered auger to loosen the soil centered around future planting holes was essential for optimal fumigation of the tree sites with the probe. In exploratory experiments, poor results were obtained when an $8-\mathrm{cm}$ diameter auger was used to loosen the soil. Use of the larger auger facilitated penetration of the fumigation probe and probably facilitated diffusion of the fumigant through the soil at the planting sites. Concentrating a relatively large fumigant dose in a small volume of soil almost certainly contributed to the efficacy of planting site spot fumigation treatments. For example, under the reasonable assumption that a $0.2-\mathrm{kg}$ dose of fumigant applied to a planting site is retained within a $0.7-\mathrm{m}$ radius of

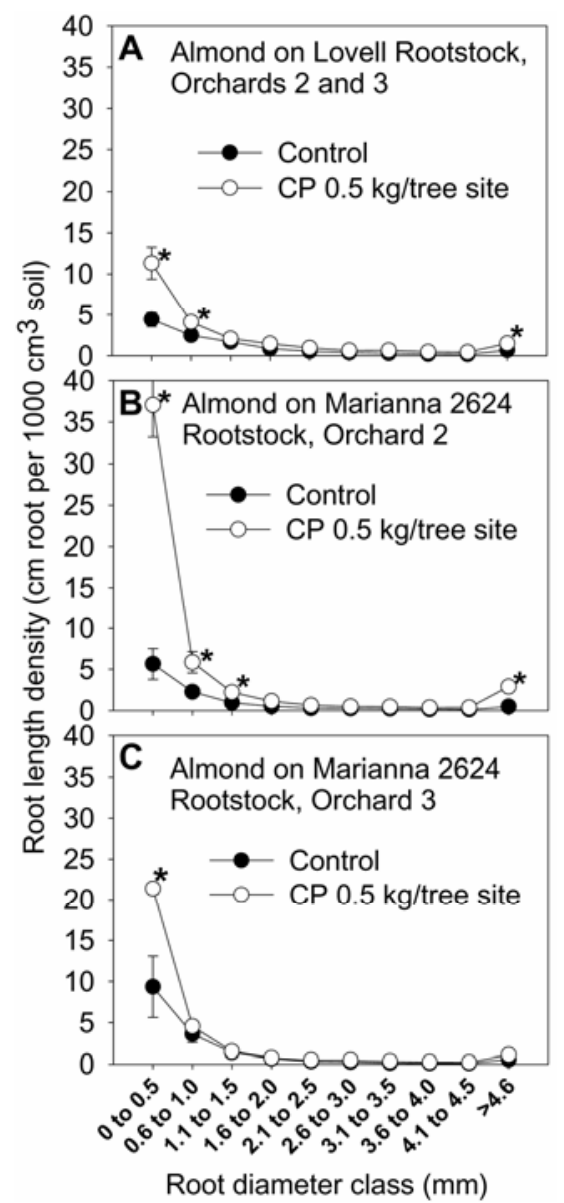

Fig. 3. Effect of pre-plant fumigation with chloropicrin (CP), injected at planting sites at soil depth of 45 to $50 \mathrm{~cm}$, on root length density of almond trees on Lovell peach and Marianna 2624 rootstocks in commercial orchards affected by replant disease near Chico, CA. Trees were planted in February 2004. On 20 October 2004, root system samples were collected from known volumes of soil around three randomly selected trees for each combination of rootstock, fumigation treatment, and orchard. Vertical bars are 95\% confidence intervals; asterisks indicate means greater than the control. a single injection point, the average application rate in the circumscribed area would be $1,300 \mathrm{~kg} / \mathrm{ha}$, about four times that of conventional broadcast rates.

Tree performance data were collected for one to three growing seasons, depending on experiment. This time span was sufficient for evaluating treatment effects during the most critical period. We have not observed severe cases of RD (i.e., high incidence of tree death or failure to grow) after successful tree establishment in the first growing season. Nevertheless, longterm research (i.e., $>3$ years) is needed and underway to comparatively assess effects and economics of broadcast, strip, and spot pre-plant fumigation treatments for orchards in different replant scenarios (i.e., in orchards at risk for RD, nematode parasitism, or both). It is possible that, in the long term, restricting the proportion of the orchard area fumigated will shorten the period of benefit from pre-plant fumigation as the tree roots explore the soil. In apparent contrast to RD, plant-parasitic nematodes such as Meloidogyne spp., Mesocriconema xenoplax, and Pratylenchus vulnus can cause progressive decline of trees for the life of an orchard, and M. xenoplax can predispose stone fruits to bacterial canker disease for up to 8 years after planting $(9,28,31)$. Therefore, tree-site spot fumigation treatments may be less effective for management of nematode parasitism than for management of RD. Our findings apply only to almond RD in absence of other replant problems.

Tree-site spot fumigation treatments, as applied in our study, were relatively labor intensive, mainly because of the site preparation requirements. Such spot treatments, which involve a hand-held probe, may involve greater risk of worker exposure to fumigant than applications using drip systems or tractor-mounted shanks. We are involved in developing potentially safer and more efficient methods for pre-plant spot fumigation.

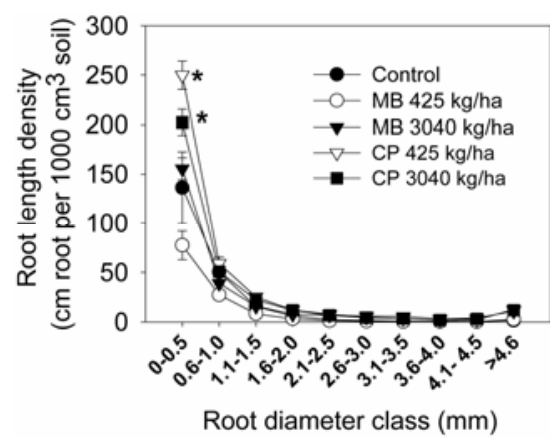

Fig. 4. Effect of pre-plant doses of methyl bromide (MB) and chloropicrin (CP), injected at soil depth of $30 \mathrm{~cm}$, on root length densities on Nemaguard peach seedlings in microplots near Parlier, CA. Seedlings were planted on 14 April 2004, and root length samples were collected the first week of November 2004. Vertical bars are $95 \%$ confidence intervals; asterisks indicate means greater than the control.
Although the orchard and microplot trials involved different locations and procedures (i.e., the Sacramento and San Joaquin valleys; use of orchard plots and microplots, and almond trees and peach rootstock seedlings, etc.), there were important similarities in the results. At all locations, the experimental trees grew satisfactorily for several weeks, but within the first growing season those planted in nonfumigated soil exhibited varying degrees of stunting, chlorosis, wilting, and defoliation. At all locations, $\mathrm{CP}$ was generally more effective than $\mathrm{MB}$ for prevention of $\mathrm{RD}$. These results suggest that $\mathrm{RD}$ has widespread geographical significance for almond and peach production in California and that $\mathrm{CP}$ is widely effective in preventing the disease.

The efficacy of the diverse fumigants in repeated orchard and microplot trials is evidence for biological mediation of RD. Although fumigants vary in toxicity to various pests and pathogens, $\mathrm{CP}, \mathrm{MB}, \mathrm{IM}$, and 1,3-D are all broad-spectrum biocides $(4,21)$. The repeated negative results from nematode sampling indicated that plantparasitic nematodes did not play an important role in RD at the test locations. Significant populations of the pin nematode were detected in control plots containing RD-affected peach seedlings in the 2002 microplot experiment, but the association between $\mathrm{RD}$ and the nematode did not hold; in plots treated with $\mathrm{MB}$ at $425 \mathrm{~kg}$ per ha, RD, but not the nematode, was present. The pin nematode is parasitic on Prunus spp. (2), but it is not regarded as an economic pest on these crops (19). It is interesting to note that $\mathrm{CP}$, which was highly effective for prevention of $\mathrm{RD}$, is $8.5 \% \mathrm{~N}$ and is relatively toxic to nitrifying bacteria (29). In a previous report, soil fumigation with either $\mathrm{CP}$ or 1,3-D resulted in a net increase in $\mathrm{N}$ availability, despite an accompanying decrease in the rate of nitrogen transformations (i.e., mineralization, nitrification) (20). Similarly, soil sterilization with steam or soil fumigation with $\mathrm{CP}$ resulted in greater ammonium accumulation and nitrogen availability for several months compared with soil fumigation with MB (29). These reports suggest that improved nitrogen availability may have contributed to the positive growth responses to $\mathrm{CP}$ in our trials, although this was not investigated. It is unlikely that the relatively small amounts of nitrogen contained in the $\mathrm{CP}$ dose used for broadcast fumigation (experiment $1,34 \mathrm{~kg} \mathrm{~N} / \mathrm{ha}$ ) and the low rate of CP in the microplots (experiments 6 to $8,36 \mathrm{~kg} \mathrm{~N} / \mathrm{ha}$ ) were solely responsible for much of the positive plant responses to those treatments.

In orchards 2 and 3, decreased root length density was associated with RD incidence. The relationship was less clear in the 2004 microplots. The orchard results suggest that the disease may be initiated on fine roots, whereas the microplot results 
suggest that the root sampling protocol for peach plants was inadequate. We have preliminary evidence for contributions of culturable fungi to etiology of RD (3). Research is clearly needed and underway on microbial contributions to RD etiology.

\section{ACKNOWLEDGMENTS}

We are grateful to Leigh Schmidt, Peggy Schrader, Harold Becherer, Jim Gartung, Nancy Goodell, Raymond Lee, Ravi Bhat, and Steve McLaughlin for excellent technical assistance. We thank Tom Trout for facilitation of microplot trials. We thank Mead Orchards, Martinez Farms, and Paiva Farms for hosting almond trials, and Burchell Nursery, Duarte Nursery, and Fowler Nursery for providing experimental trees. This work was supported in part by funding from the Almond Board of California and UC SAREP.

\section{LITERATURE CITED}

1. Barazani, O., and Friedman, J. 1999. Allelopathic bacteria and their impact on higher plants. Crit. Rev. Plant Sci. 18:741-755.

2. Braun, A. L., and Lownsbery, B. F. 1974. The pin nematode, Paratylenchus neoamblycephalus, on Myrobalan plum and other hosts. J. Nematol. 6:136.

3. Browne, G. T., Connell, J. H., and McLaughlin, S. T. 2003. Determining causes and control measures for an almond replant disease. (Abstr.) Phytopathology 93:S12.

4. Duniway, J. M. 2002. Status of chemical alternatives to methyl bromide for pre-plant fumigation of soil. Phytopathology 92:1337-1343.

5. Gilmore, A. E. 1959. Growth of replanted peach trees. Proc. Am. Soc. Hortic. Sci. 73:99111.

6. Giovannini, D., Liverani, A., and Bordoni, P. 1998. Final observations on the behavior of peach rootstocks on sites with replant problems. Riv. Frutticoltura Ortofloricoltura 60:67-74.

7. Gur, A., and Cohen, Y. 1989. The peach replant problem - some causal agents. Soil Biol. Biochem. 21:829-834.

8. Hartmann, H. T., Kester, D. E., Davies, F. T., and Geneve, R. L. 1997. Plant Propagation: Principles and Practices. Prentice-Hall, Upper
Saddle River, NJ.

9. Hattingh, M. J., and Roos, I. M. M. 1995. Bacterial Canker. Pages 48-50 in: Compendium of Stone Fruit Diseases. J. M. Ogawa, ed. American Phytopathological Society, St. Paul, $\mathrm{MN}$.

10. Hine, R. B. 1961. The role of fungi in the peach replant problem. Plant Dis. Rep. 45:462466.

11. Hooper, D. F. 1970. Laboratory methods for work with plant and soil nematodes. Pages 3438 in: Tech. Bull. 2. J. F. Southey, ed. Ministry of Agriculture, Fish and Food, London.

12. Jenkins, W. R. 1964. A rapid centrifugalflotation technique for separating nematodes from soil. Plant Dis. Rep. 48:692.

13. Kester, D. E., and Grasselly, C. 1987. Almond rootstocks. Pages 265-293 in: Rootstocks for fruit crops. R. C. Rom and R. F. Carlson, eds. John Wiley \& Sons, New York.

14. Koch, L. W. 1955. The peach replant problem in Ontario. I. Symptomotology and distribution. Can. J. Bot. 33:450-460.

15. Larsen, H. J. 1995. Replant Disorders. Pages 46-47 in: Compendium of Stone Fruit Diseases. J. M. Ogawa, ed. American Phytopathological Society, St. Paul, MN.

16. Mai, W. F., and Abawi, G. S. 1978. Determining the cause and extent of apple, cherry, and pear replant disease under controlled conditions. Phytopathology 68:1540-1544.

17. Matkin, O. A., and Chandler, P. A. 1957. The U.C.-type soil mixes. Pages 68-85 in: The U.C. system for producing healthy container-grown plants. K. F. Baker, ed. University of California, Oakland.

18. Mazzola, M. 1998. Elucidation of the microbial complex having a causal role in the development of apple replant disease in Washington. Phytopathology 88:930-938.

19. McKenry, M. V. 1996. Nematode parasites. Pages 220-223 in: Almond Production Manual. W. C. Micke, ed. University of California, Divsion of Agriculture and Natural Resources, Oakland

20. Nira, R., Hashimoto, T., Matsuzaki, M., and Nishimune, A. 1996. Nitrogen transformations and availability in soils with application of fumigants. Soil Sci. Plant Nutrition 42:261-268.
21. Ohr, H. D., Sims, J. J., Grech, N. M., Becker, J. O., and McGiffen, M. E., Jr. 1996. Methyl iodide, an ozone-safe alternative to methyl bromide as a soil fumigant. Plant Dis. 80:731735 .

22. Patrick, Z. A. 1955. The peach replant problem in Ontario. II. Toxic substances from microbial decomposition products of peach root residues. Can. J. Bot. 33:461-486.

23. Probesting, E. L. 1949. The peach replant problem. Hortic. News 30:2213-2214.

24. Probesting, E. L. 1950. A case history of a "peach replant" situation. Proc. Am. Soc. Hortic. Sci. 56:46-48.

25. Probesting, E. L., and Gilmore, A. E. 1941. The relation of peach root toxicity to reestablishing of peach orchards. Proc. Am. Soc. Hortic. Sci. 38:21-26.

26. Schippers, B., Bakker, A. W., and Bakker, P. A H. M. 1987. Interactions of deleterious and beneficial rhizosphere microorganisms and the effect of cropping practices. Annu. Rev. Phytopathol. 25:339-358.

27. Strand, L. L. 1999. Integrated pest management for stone fruits. University of California, Division of Agriculture and Natural Resources, Oakland.

28. Strand, L. L. 2001. Integrated pest management for almonds. University of California Division of Agriculture and Natural Resources, Oakland.

29. Tanaka, S., Kobayashi, T., Iwasaki, K., Yamane, S., Maeda, K., and Sakurai, K. 2003 Properties and metabolic diversity of microbial communities in soils treated with steam sterilization compared with methyl bromide and chloropicrin fumigations. Soil Sci. Plant Nutrition 49:603-610.

30. Uyemoto, J. K., Connell, J. H., and Greer, C. A. 1996. Effects of union mild etch, a newly recognized disorder, on almond scions growing on Marianna 2624 rootstock. Plant Dis. 80:1406-1408.

31. Westerdahl, B. B., and McKenry, M. V. 2002. Diseases caused by nematodes. Pages 11-14 in: Compendium of Nut Crop Diseases in Temperate Zones. B. L. Teviotdale, T. J. Michailides, and J. W. Pscheidt, eds. American Phytopathological Society, St. Paul, MN. 